Considerable evidence exists regarding the adverse effect of continued smoking on vein graft patency rates and early operative mortality and morbidity. One study has reported a reduction in the relative survival of younger patients who smoke, ${ }^{36}$ and, although little work has been done, it would seem likely that continued smoking will negate the beneficial effect of surgery in patients whose life expectancy would be expected to improve after operation. Subjecting patients who continue to smoke, and for whom the only indication for operation is the relief of angina, to the increased risks of surgery in the face of a remediable cause is not justified.

1 Nikutta P, Lichtlen PR, Wiese B, Jost S, Dekkers J, Rafflenbeul W, et al Influence of cigarette smoking on the progression of coronary artery disease within three years: results of the INTACT study. $7 \mathrm{Am}$ Coll Cardio 1990;15:181A

2 Fielding JE. Smoking. Health effects and control (part one). $N$ Engl $\mathcal{F}$ Med 1985;313:491-8.

3 Suttorp MJ, Kingma JH, Vos J, Koomen EM, Tijssen JGP, Vermeulen FEC et al. Determinants for early mortality in patients awaiting coronary artery bypass graft surgery: a case-control study. Eur Heart f 1992;13:238-42.

4 CASS Principal Investigators and their Associates. Coronary artery surger study (CASS): a randomised trial of coronary artery surgery: quality of life in patients randomly assigned treatment groups. Circulation 1983;68: in patient

5 Peduzzi P, Hultgren H, Thomsen J, Detre K. Ten year effect of medical and surgical therapy on quality of life: Veterans Administration cooperative surgical therapy on quality of life: Veterans Administration
study of coronary artery surgery. Am $\mathcal{F}$ Cardiol 1987;59:1017-23.

6 Silverman KJ, Grossman W. Angina pectoris: natural history and strategies for evaluation and management. NEngl f Med 1984;310:1712-7.

7 Cameron EWJ, Walker WS. Coronary artery bypass surgery. BMf 1990;300: 1219-20.

8 Badimon JJ, Ip J, Badimon L, Fuster V. Thrombosis and accelerated atherosclerosis in coronary bypass surgery and restenosis after percutaneous transluminal coronary angioplasty: implications for therapy. Coronary Artery Disease 1990;2:170-9.

9 ACC/AHA Task Force. Guidelines and indications for coronary artery bypas graft surgery. A report of the American College of Cardiology/American Heart Association Task Force on assessment of diagnostic and therapeutic cardiovascular procedures. $7 \mathrm{Am}$ Coll Cardiol 1991;17:543-89.

10 Smith SH, Geer JC. Morphology of saphenous vein-coronary artery bypass grafts: 7-1 16 months postoperatively. Arch Pathol Lab Med 1983;107:13-8.

11 Goldman S, Copeland J, Moritz T, Henderson W, Zadina K, Ovitt T, et al. Improvement in early saphenous vein patency after coronary artery bypass surgery with antiplatelet therapy: results of a Veterans Administration cooperative study. Circulation 1988; $77: 1342-52$.

12 Bosch X, Perez-Villa F, Sanz G. Effect of smoking habits on the preventive effect of aspirin and dipyridamole on early aortocoronary bypass occlusion. Eur Heart f 1991;12:170.

13 Levine PH. An acute effect of cigarette smoking on platelet function. Circulation 1973;48:619-23.

14 Galea G, Davidson RJL. Haematological and haemorheological changes associated with cigarette smoking. 7 Clin Pathol 1985;38:978-84.

15 Fitzgerald GA, Oates JA, Nowak J. Cigarette smoking and haemostatic function. Am Hear f 1988;115:267-71.
16 Wilhelmsen L, Svardsudd K, Korsan-Bengtsen K. Fibrinogen as a risk factor for stroke and myocardial infarction. N Engl I Med 1984;311:501-5.

17 Fuster V, Chesebro JH, Frye RL, Elveback LR. Platelet survival and the development of coronary artery disease in the young adult: effects of cigarette smoking, strong family history and medical therapy. Circulation $1981 \cdot 63 \cdot 546-5$

18 Solymoss BC, Nadeau P, Millette D, Inge B, Campeau L. Late thrombosis of saphenous vein coronary bypass grafts related to risk factors. Circulation 1988;78(suppl I): 140-3.

19 Wiseman S, Kenchington G, Dain R, Marshall CE, McCollum CN, Greenhalgh RM, et al. Influence of smoking and plasma factors on the patency of femoropopliteal grafts. BM7 1989;298:643-6.

20 Greenhalgh RM, Laing SP, Cole PV, Taylor GW. Smoking and arterial reconstruction. Br F Surg 1981;68:605-7.

21 Nietzel GF, Baboriak JJ, Pintar K, Quershi I. Atherosclerosis in aortocoronary bypass grafts. Morphological study and risk factor analysis 6-12 years after surgery. Arteriosclerosis 1986;6:594-600

22 Campeau L, Enjalbert M, Lesperance J, Bourassa MG, Kwiterovitch P, Wacholder $\mathbf{S}$, et al. The relation of risk factors to the development of atherosclerosis in saphenous vein bypass grafts and the progression of the disease in the native circulation. A study 10 years after aortocoronary bypas surgery. N Engl f Med 1984;311:1329-32.

23 Gordon DJ, Probstfield JL, Garrison RJ, Neaton JD, Castelli P. High density lipoprotein cholesterol and cardiovascular disease: four year prospective American studies. Circulation 1989;79:8-15.

24 Stampfer MJ, Sacks FM, Salvini S, Willett WC, Hennekens CH. A prospective study of cholesterol. apolipoproteins and the risk of myocardial infarction. N Engl f Med 1991;325:373-81.

25 Criqui MH, Wallace RB, Heiss G, Mislakel M, Schonfeld G, Jones GTL. Cigarette smoking and plasma high-density cholesterol. Circulation 1980;62 (suppl IV):70-6.

26 FitzGibbon GM, Leach AJ, Kafka HP. Atherosclerosis of coronary artery bypass grafts and smoking. Can Med Assoc f 1987;136:45-7.

27 Vekkala $\mathrm{K}$, Jarvinen A, Virtanen K, Keto P, Pellinen T, Salminen US, et al Indications for and risks in reoperation for coronary artery disease. Scan $\mathfrak{g}$ Thorac Cardiovasc Surg 1990;24:1-6.

28 Dougenis D, Naik S, Hedley Brown A. Is repeated coronary surgery for recurrent angina cost effective? Eur Heart $f$ 1992;13:9-14.

29 Nair UR, Campell CC, Dark JF, Deiranya AK, Lawson RA, Mousalli H, et al. Reoperation for recurrent coronary artery and graft disease. A review of 73 patients in a group of 2573 consecutive first operations. $\mathcal{F}$ Cardiovasc Surg 1989;30:656-60.

30 Ivert TS, Ekestrom S, Peterffy A, Welti R. Coronary artery reoperations. Early and late results in 101 patients. Scand f Thorac Cardiovasc Surg 1988;22:111-8

31 Warner M, Offord KP, Warner ME, Lennon RL, Conover MA, JanssonSchumacher $\mathrm{U}$, et al. Role of preoperative cessation of smoking and other factors in postoperative pulmonary complications: a blinded prospective factors in postoperative pulmonary complications: a blinded prospective
study of coronary artery bypass patients. Mayo Clin Proc 1989;64:609-16.

32 Carrel T, Scmid ER, von Segesser L, Vogt M, Turina M. Preoperative assessment of the likelihood of infection of the lower respiratory tract after cardiac surgery. Thorac Cardiovasc Surg 1991;39:85-8.

33 Nagachinta T, Stephens M, Reitz B, Polk BF. Risk factors for surgical wound infection following cardiac surgery. F Infect Dis 1987;156:967-73.

34 Engblom E, Ronnemaa T, Hamalainen H, Kallio V, Vantinen E, Knutz LR Coronary heart disease risk factors before and after bypass surgery: results of a controlled trial on multifactorial rehabilitation. Eur Heart f 1992;13:232-7.

35 Brook RH, Park RE, Winslow CM, Chassin MR, Winslow CM, Hampton JR Diagnosis and treatment of coronary disease: a comparison of doctor attitudes in the USA and the UK. Lancet 1988;ii:750-3.

36 Ramanathan KB, Vander Zwaag R, Maddock V, Kroetz FW, Sullivan JM Mirvis DM. Interactive effects of age and other risk factors on long term survival after coronary artery surgery. F Am Coll Cardiol 1990;15:1493-9.

\title{
Refusing to treat smokers is unethical and a dangerous precedent
}

\section{Matthew Shiu}

Should cigarette smokers be offered coronary artery bypass graft operations? Some specialists are adamant that they should not unless they promise to give up smoking. With increasing resource limitations, such views may soon become accepted policy. Some of the argument would seem well founded on several fronts: the known adverse effect of smoking on the use of anaesthetics; the known adverse effects of continued smoking on graft survival and progression of coronary artery disease; and limited resources with ever increasing demand.

There is no doubt that cigarette smoking is harmful to coronary arteries. The medical profession is united in condemning smoking and has been fairly successful. Working as a general practitioner and with a special interest in cardiology, I spend much of my time getting patients off cigarettes. There is, however, a small group of patients who truly cannot give up their habit. All anti-smoking clinics have such examples. The medical profession does not have a satisfactory treatment for true cigarette addiction. So is it right to completely deny this group of high risk patients a recognised form of treatment because they cannot give up smoking? According to a spokesperson at the Medical Defence Union, should a case ever be brought to the court it would be difficult to defend such a stand if treatment was refused solely on those grounds. Some patients are denied investigations on the grounds that surgery will not be offered.

The outcome of coronary artery surgery can be compromised by other factors such as hypertension, diabetes, age, female gender, obesity, and hypercholesterolaemia. These are all accepted as deleterious but not absolute overriding contraindications. Is it right to isolate one risk factor and make a firm policy without taking other issues into consideration? Diabetic patients are operated on-even the ones who cannot stay on a strict diet. Will patients be refused surgery because they cannot stick to a cholesterollowering diet?

Resources are limited and will continue to be limited. If we examine the resource issue more closely, however, the argument does not seem so strong. The financial cost of not operating is often much higher 
than the cost of operating. Patients not given operations are unemployable, need sickness benefits, remain on multiple expensive medication, and require repeated hospital admissions for chest pains. Money is saved on the surgical units at the expense of the state.

\section{"Has self infliction in any other condition ever barred patients from receiving proper care in Britain?"}

But the real issue is not money but ethics. Limited resources should be a problem for the health care system. Instead of withholding treatment, doctors should use their influence in the proper channel.

One surgeon said he would not operate on smokers even with all the resources available in the NHS for he does not wish to construct walls for people who are busy knocking them down. If we accept this ar'ment, then more than half the genitourinary clinics cal. close down. Asthmatic smokers will not be given nebulisers. It has been argued that damage caused by smoking is self inflicted, hence smokers do not deserve treatment. But has self infliction in any other condition ever barred patients from receiving proper investigation and treatment in Britain? I would like to believe that up to now doctors have always treated patients, irrespective of the degree of culpability of the person concerned. Drunken victims of road traffic accidents are never made to promise total alcohol abstinence before they are given first aid. Patients who attempt suicide are always treated. My view is that once we accept an absolute bar to surgery for smokers, we would next refuse lifesaving treatment to asthmatic smokers and soon may well be on the slippery slope to withholding treatment for the unmotivated and the unfit.

\title{
Human frailty should not be penalised
}

\author{
Roger Higgs
}

"Well, yes, I must admit I smoke."

"I am glad to hear it. A man should always have an occupation of some kind."

Lady Bracknell's marital history taking from the hapless Mr Worthing is still as funny as when Oscar Wilde introduced The Importance of Being Ernest to the stage a hundred years ago. But since then attitudes to smoking and to medical care have changed beyond recognition. The modern $\mathrm{Mr}$ Worthing's misfortune is no longer that he was born in a handbag, with or without handles. For the young man now who smokes and has coronary artery disease, the uncertainty is from the budgetary plans of the health authority over which Mrs Bracknell now presides.

M J Underwood and J S Bailey give her clear advice. This is an expensive operation, and should not be offered without careful thought. In an area of great complexity, guidelines are vital. Apart from the technical issues, there have been traditionally two separate levels of decision making about such treatments. The first is that of indications (or contraindications). At this level the evidence is carefully considered, based it is hoped on good research, and guidelines are established about the circumstances in which a particular intervention would be helpful. This is quite separate from the consideration of an individual case and should apply whatever the particular circumstances of the health care system in question.

The second level is that of engaged clinical judgment, or advice about an individual's medical care. Here the first level clinical guidelines are of great importance but are certainly not the only issues which lead to the decision. Of course it would be quite wrong from any point of view to recommend a procedure for anyone who would stand to run great risks and reap few benefits from it. But where a positive balance is to be struck, however small, other factors must be taken into account: the patient's wishes, the overall clinical picture, the social situation, and so forth. How widely the net is to be cast is not formalised, but this level of decision making is shared between doctor and patient. The autonomy of both is respected, and the need for mutual exchange of information and understanding underpins the decision. Medical care is not based on prescience but on probability-good guesses, perhaps, but no more. Nobody can predict with certainty the

degree of benefit (or the lack of it) in the individual case, but it is assumed by all that the doctor is advising with the patient's manifest best interests in mind.

In between these levels, however, is a third and quite distinct type of decision making, based on the resources available. In a closed system, one person's benefit may be another person's loss or lack of benefit.

\section{"To disenfranchise certain groups for certain types of expensive health care ... should make us feel uneasy."}

There is nothing new in this, except that until recently this has not been part of explicit clinical decision making at the other two levels. This causes confusion unless the reasons are clear and are made explicit. If we are forced to take resourcing factors into account, these have to be openly explained. The health authority must be told by clinicians what benefit could be obtained for whom and to what degree. The cut off point either way is for negotiation. Likewise, the clinician must be open to the patient about the degree of benefit and risks of harm to the individual, and the degree of benefit that the system can offer. Patients should be told which of the three levels they are receiving advice on: whether the treatment is indicated, whether it can be afforded, or whether in balance it is the best for them.

If the information to make the first level decision is available and valid, a scoring system for the individual level could presumably be created which could aid in the individual case. But within this, as Matthew Shiu points out, for coronary artery surgery, smoking would be just one factor among many, even before personal issues were taken into account. The obese diabetic non-smoker who takes no exercise and has a poor family history, for example, might well stand to reap fewer benefits than the exercising smoker without other risk factors, and so on. In selection for surgery, if we abandon the universally available queue and reject a lottery we should presumably be aiming at more overall quantification as an aid in the traditional process of clinical judgment.

Good clinical judgment is thus seen as consistent and 